\title{
Implementation of The Islamic Local Regulations in Bulukumba Regency
}

\author{
Zakirah Zakirah $^{1}$, Jumliadi Jumliadi ${ }^{2}$, Muhammad Arsyam ${ }^{3}$, Herianto Herianto ${ }^{4}$, Muhammad Rusli ${ }^{5}$ \\ Andi Mujaddidah Alwi ${ }^{6}$ \\ ${ }^{1}$ Institut Agama Islam Negeri (IAIN) Sultan Amai Gorontalo, Indonesia \\ Email: zakirahira17@gmail.com \\ ${ }^{2}$ Sekolah Tinggi Agama Islam (STAI) Darul Dakwah Wal-Irsyad (DDI) Kota Makassar, \\ Indonesia \\ Email: jumliadimh@gmail.com \\ ${ }^{3}$ Sekolah Tinggi Agama Islam (STAI) Darul Dakwah Wal-Irsyad (DDI) Kota Makassar, \\ Indonesia \\ Email: arsyam0505@gmail.com \\ ${ }^{4}$ Sekolah Tinggi Keguruan dan Ilmu Pendidikan (STKIP) YAPTI Jeneponto, Indonesia \\ Email: antoherianto47@gmail.com \\ ${ }^{5}$ Sekolah Tinggi Agama Islam (STAI) Darul Dakwah Wal-Irsyad (DDI) Kota Makassar, \\ Indonesia \\ Email: muhammadruslitompo89@gmail.com \\ ${ }^{6}$ Sekolah Tinggi Agama Islam (STAI) Darul Dakwah Wal-Irsyad (DDI) Kota Makassar, \\ Indonesia \\ Email: dhidapijarjingga@gmail.com
}

\begin{abstract}
One of the historical breakthroughs in political Islam in Indonesia after the collapse of the New Order regime was the emergence of the regional autonomy policy, in which, hypothetically, diffusion of policies involving geographic aspects, institutions, relations between policy actors, and local culture occured. Islamic local regulations have been issued to regulate ehavior and authority to supervise the community whether they run their religion properly or not. Therefore, the government of the Bulukumba Regency made regional policies in the framework of sharia regulations, which became a political process of public policy to be a reference in analyzing the phenomena behind regulating the communities' lives. This research used a qualitative method with a descriptive approach. The data were collected by in-depth and structured interviews with research objects, namely the government of Bulukumba Regency, the Ministry of Religious Affairs of Bulukumba Regency, the Ulema Council, religious leaders, community leaders, youth leaders, community organizations, and NGOs living in Bulukumba Regency. This research focused on the role of actors and institutions involved in implementing religious regulations whether or not they have been in line with their ideals in forming a religious community and with the vision of the Bulukumba local government. The results showed that the Bulukumba local government's policy in formulating Islamic local regulations required the community to practice Islam based on Al-Qur'an and al-Hadith to eradicate criminal acts and increase faith and piety. Islamic local regulations have been implemented using institutional, group, incremental, and political system approaches, as a form of political relations, which have begun to develop among religious organizations (NU, Muhammadiyah, and others).
\end{abstract}

Keywords: Implementation; Policy and Islamic Local Regulations 


\section{Introduction}

In Muslim countries, efforts to implement Islamic sharia have undergone ups and downs such as the ups and downs of democracy [1-2]. In Indonesia, for example, the opening of a democratic faucet which was marked by the collapse of the New Order (ORBA) gave rise to a new phenomenon that might have never been imagined before. In an effort to uphold Islamic sharia in Indonesia both constitutionally through political channels or unconstitutionally, such rebellion, is part of a long history of the struggle of Indonesian Muslims to implement Islamic sharia.

An ideological debate about the basis of the state has taken place since this nation was about to proclaim its independence. The idea proposed by the fighters of "Santri Islam" received very strong challenges from the fighters of "Nationalist Islam" [3-4]. The collapse of the ORBA also had an impact on changing the system of government, from centralized to decentralized, in which regions had greater authority to regulate their respective regions. In the reform era with the issuance of Law No. 22 of 1999 concerning Regional Autonomy [5], which was later revised to Law No. 32 of 2004 concerning Local Government, seemed to be a new chapter for the political participation of the Indonesian people in the realm of democracy [6].

The opening of democratic faucets and the changing of government systems have inspired regions to uphold sharia as those take place in Nangroe Aceh Darussalam, Banten, Tasikmalaya and Bulukumba in South Sulawesi. Bulukumba as one of the regencies in South Sulawesi Province, the idea to uphold Islamic sharia was initially dominated by the Preparatory Committee for Enforcement of Islamic Sharia (KPPSI). Therefore, the local government of Bulukumba regency, with a change in the system of government, responded quickly by rolling out the idea of implementing Islamic sharia, in this case the Regent of Bulukumba, Andi Patabai Pabokori.

In an effort to understand the views and responses of the Muslim community to the local regulations, especially the local regulation on reading and writing Al-Quran for students and future brides and grooms in Bulukumba, various studies have been carried out to depict the long struggle of Muslims and their difficulties in implementing the ideals of Islamic sharia enforcement into state life. Studies of some of the predecessor experts provided a lot of data. For example, research conducted by Faisal [7], which looked at the basics and maps of ulama's thinking on the idea of applying Islamic sharia. In line with Ma'arif's research [8], the phenomenon of mushrooming the regional desires to implement Islamic sharia alone was not enough.

The religious local regulations in Bulukumba, such as Local Regulation No. 3 of 2002 concerning Prohibition, Supervision, Issuance and Sales of Liquor, Local Regulation No. 2 of 2003 concerning Management of Professional Zakat, Infaq, and Sadaqah replaced by Local Regulation No. 7 of 2015 concerning Management of Zakat, Local Regulation No. 5 of 2003 concerning Muslim and Muslim clothing, and Local Regulation No. 6 of 2003 concerning Reading and Writing Al-Quran for Students and Future Brides and Grooms [9].

\section{Research Method}

This study was a descriptive qualitative research [10]. It used qualitative observations of the object under study with descriptive data, in the form of written words or oral information from observed people and behaviors, in other words, the writer noted, analyzed and interpreted existing conditions. In this study, accuracy and exactitude of data sources were obtained from the so-called population, namely all Muslim communities in Bulukumba Regency which were spread in 10 districts. Considering that the population was quite large, the researchers conducted a purposive sampling thus a sample that could truly provide 
a picture of the actual condition or representative sample was obtained [11]. The data collection techniques were in the form of observation and interviews. Subsequently, data analysis was conducted using data reduction components, data presentation and data verification.

\section{Result and Discussion}

Administratively, population distribution in Bulukumba Regency can be explained as follows. The Bugis tribe inhabits Bulukumba, Sinjai, Wajo, Pinrang, Pare-pare, Luwu and Enrekang. Makassar tribes inhabits Makassar, Gowa, Takalar, Jeneponto, Bantaeng, Selayar, Maros, Pangkep and Kepulauan. The Mandar tribe (now Sulawesi Barat) inhabits the districts of Polmas, Majene and Mamasa. The Toraja tribe inhabits Tanah Toraja and Toraja Utara [12-13].

The inner attitude of the Bulukumba community to develop the mandate of unity and to realize mutual safety for the achievement of the development goals of physical-spiritual, material-spiritual, world-afterlife is ripened through a principle of "mali siparappe and tallang sipahua" (helping one another in goodness and mutual respect). The nuance of morality is the thing underlying the emergence of elaboration slogan "Bulukumba Berlayar". The concept "Berlayar" is an acronym for causality that reads "bersih lingkungan dan alam yang ramah" (clean environment and friendly nature). The philosophy contained in the slogan can be seen from three sides: history, culture and religion.

In the context of Islamic politics, the existence of autonomy and decentralization is the entry point to carry out Islamization in all fields, including through the enactment of local regulations under Islamic shades. Islamization for Islamic parties is a living agenda, hence it becomes the main reason why the issue of Islamic sharia is never abandoned by political parties [14-15]. Moreover, the implementation of Islamic sharia in villages as a pilot project is developing very rapidly, even exceeding the local regulations of regency. One example is Padang village, Gantarang District, which stipulates "Village Regulations" containing rules on adultery (whip 100 times), qacaf alias accusing someone doing adultery (80 times whip or delegated to the police), liquor (40 times whip) and qishash crime (equal retaliation) for acts of abuse. The Islamic sharia local regulations in Bulukumba Regency also has several differences including social, cultural, political and intellectual factors carrying a very significant influence in determining the someone's shape and understanding towards Islamic sharia.

There are many reasons that often arise side by side with the religion formalization in the regions, including: First, the religion formalization through local regulations is considered as a solution to society and nationality problems. Second, formalization is considered as a representation of the people's wishes in the regions. Third, political interests are so thick as an integral part of the desire to formalize religion through local regulations made in accordance with the wishes of their local leaders [16].

This study showed that there were a number of interesting things need to be examined in relation to the emergence of the Islamic sharia-nuanced local regulation in the Bulukumba Regency. In the interviews with the pioneers formulating the Islamic sharia-nuanced local regulation, the researcher asked whether the Sharia-nuanced local regulation was a response of the local government to uphold local democracy in the context of regional autonomy. Most of them answered that the main purpose of making an Islamic sharia-nuanced local regulation was not because the government wanted to uphold democracy in the region, rather it was a need in the Bulukumba regency, which was predominantly Muslim. It was in line with Syarifuddin saying that the implementation of the Islamic sharia-nuanced local regulation in Bulukumba regency was a necessity since the majority of the population was Muslim. Such moment came when the regional autonomy existed, say like a tit for tat, and it met the community's 
will, the local regulations and with the existence of regional autonomy. Therefore it was not because of the regional autonomy, regional autonomy only provided opportunities, while such desire grew because the community wanted it. And for it was the community's will, there was no objection from nonMuslims [17].

It was the socio-religious conditions of the community that became the concern of the leaders in the Bulukumba regency hence it was necessary to implement an Islamic sharia-nuanced local regulation. As Pabokori stated that religious practice of the community was already very bad, everywhere we saw drunken people, many young people were not able to read Al-Qur'an, whereas in this area the majority of the population was Muslim (99.8\%). One thing for sure that even though the community claimed to be Muslims, they were only Muslims in their ID Cards (KTP), thus it was the reason for the birth of crash program for religion. Then to increase the pressure on the crash community, the religious program was mixed into the local regulation by paying attention to the condition of Bulukumba, which had always been famous as a religious community after the arrival of Datuk ri Tiro marked as the beginning of the Muslim revival in this region [18].

According to Sahiruddin, this stipulated local regulation concerned Islamic teachings aimed at how Muslims know well about Islamic teachings. It is because when talking about the Islamic sharia, our memories are directly focused on the issue of cutting off hands, stoning and whipping. Whereas it was not the case in Bulukumba. The implementation of the local regulation in Bulukumba regency was about the use of headscarves and an increase in the number of students who are good at reading and writing Al-Qur'an [19]. In addition, this local regulation aimed to enable Muslims to apply Islamic teachings well in their daily lives.

From the description above, it shows that the main reason in making the local regulation on Islamic sharia is not in the framework of upholding local democracy and is not a response to the previous law, but rather it is because many people were less able to read Al-Qur'an and as an application of community morality.

\subsection{Community's Response towards the Implementation of Islamic Sharia Local Regulation in Bulukumba Regency}

This study took one of the stipulated local regulations, Local Regulation No. 06 of 2003 concerning Reading and Writing Quran for students and future brides and grooms in Bulukumba. This regulation is very much in touch with people's lives, especially their religious lives. The positive response is illustrated in the following table:

Table 1. Community's Response towards the Existence of Local Regulation No. 06 of 2003

\begin{tabular}{|l|c|c|}
\hline \multicolumn{1}{|c|}{ Response } & $\begin{array}{c}\text { Amount of } \\
\text { respondents }\end{array}$ & Percentage \\
\hline Strongly Agree & 16 & 53.34 \\
\hline Agree & 12 & 40.00 \\
\hline Disagree & 1 & 3.33 \\
\hline Strongly Disagree & 1 & 3.33 \\
\hline \multicolumn{1}{|c|}{ Total } & 30 & $100 \%$ \\
\hline
\end{tabular}

The analysis on the above table showed that 16 respondents stated strongly agree with Local Regulation No. 06 of 2003. A total of 12 respondents agreed, 1 respondent disagreed and 1 respondent strongly disagreed. From this data, it can be concluded that the community of Bulukumba welcomed 
with enthusiasm as evidenced by the high percentage of answers stating agreement, $53.34 \%$ strongly agreed and $40.00 \%$ agreed, very small percentage of people who rejected this regulation, only $3.33 \%$ disagreed and $3.33 \%$ strongly disagreed.

The Local Regulation concerning Reading and Writing Al-Qur'an was widely known and evenly distributed by the community of Bulukumba. This information is available in the following table:

Table 2 Community's knowledge of the existence of Local Regulation No. 06 of 2003

\begin{tabular}{|l|c|c|}
\hline \multicolumn{1}{|c|}{ Response } & $\begin{array}{c}\text { Amount of } \\
\text { Respondents }\end{array}$ & Percentage \\
\hline $\begin{array}{l}\text { Have already known of the } \\
\text { existence of Local Regulation } \\
\text { No. 06 of 2003 }\end{array}$ & 28 & 93.33 \\
\hline $\begin{array}{l}\text { Have not known of the existence } \\
\text { of Local Regulation No. 06 of } \\
2003\end{array}$ & 2 & 6.67 \\
\hline \multicolumn{1}{|c|}{ Total } & $\mathbf{3 0}$ & $\mathbf{1 0 0 \%}$ \\
\hline
\end{tabular}

Analysis result of the table above revealed that 28 respondents already knew of the existence of Local Regulation No. 06 of 2003, whereas the other two did not. It shows that $93.33 \%$ of respondents have known the existence of Local Regulation No. 06 of 2003 and $6.67 \%$ did not. It could be inferred that the community's knowledge of the Local Regulation concerning Reading and Writing Al-Qur'an was very high. It all was inseparable from the efforts of intense socialization, especially in remote areas.

Additionally, this Local Regulation No. 06 of 2003 had become a barometer of admission of new students in the Bulukumba Regency. All prospective students should pass Al-Quran reading test, as well as having to show a certificate stating that they were able to read Al-Qur'an. However, this practice was still flexible, meaning that there was still tolerance for students who were unable to read Al-Qur'an. Usually, the school organizer asked their parents to make a statement that they were ready to guide their children to read Al-Qur'an until a mutually agreed deadline.

Basically, each school had accommodated the aspirations of this local regulation and applied it in their respective schools. In some schools, if there found students who were unable to read Al-Qur'an, they were given sanctions in the form of postponement of the exam. Not only for students in schools, future brides and grooms who are unable to read Al-Qur' an were given sanctions by PPN/village priests in the form of postponement of the marriage akad, which means the bride and groom could not get married until they were able to read Al-Qur'an.

This article shows that the policy of the local government of Bulukumba in formulating a religious local regulation requires that community practice Islam based on Al-Qur'an and al-Hadith, in an effort to eradicate criminal acts and increase faith and piety [20]. It is not in line with Dalmeri's study saying that the implementation of the Islamic sharia-based regional regulation was unqualified because it was simplistic, no clear concept, and not based on a serious analysis of various contemporary problems in community [21]. The facts show that the basis of the arguments on which the Islamic sharia was based appeared to have a thicker political content. Finally, this article states that the implementation of the Islamic sharia local regulation in Bulukumba is a decision having an impact on the education world and using an institutional approach. 


\section{Conclusion}

This study concluded two things. First, the emergence of the Islamic sharia local regulation in Bulukumba was motivated by the issuance of Law no. 22 of 1999 concerning Regional Autonomy, which was later revised into Law No. 32 of 2004 concerning Regional Government, allowing regions that are predominantly Muslim to implement Islamic sharia-nuanced local regulation. Second, the implementation of the Islamic sharia local regulation in Bulukumba used institutional, group, incremental and political systems approaches as a form of political relations began to develop among religious organizations (NU, Muhammadiyah, and so on) and also had an impact on decisions in education world.

\section{References}

[1] N. Saada 2020 Understanding the religious controversy around democracy in Muslim-majority societies: An educational perspective Citizenship Teaching \& Learning, $15163-78$

[2] E. J. Powell, S. C. McDowell, R. O’Brien, \& J. Oksasoglu 2020 Islam-based legal language and state governance: democracy, strength of the judiciary and human rights Constitutional Political Economy, 1-37

[3] A. Nakissa 2020 Security, Islam, and Indonesia: An Anthropological Analysis of Indonesia's National Counterterrorism Agency Bijdragen tot de taal-, land-en volkenkunde/Journal of the Humanities and Social Sciences of Southeast Asia, 176 2-3 203-239

[4] H. A. Said, L. K. Pongsibanne, \& L. Shobariya 2020 Islamic Relations, Local Tradition (Nahdlatul Ulama, Muhammadiyah, and The Ethnic Baduy) and Their Effects on Religious Life Patterns In Indonesia European Journal of Research in Social Sciences, 81

[5] A. Yakub, A. B. A. Ghani, \& M. S. I. Anwar 2020 Urgency of Political Decentralization and Regional Autonomy in Indonesia: Local Perspectives Journal of International Studies, 14 141-150

[6] A. Wahyono, \& M. Illiyani 2020 The Concept of the Right to Management of Coastal Communities in the Regional Autonomy Era: Experience from Community Assistance to Obtain the Right to Manage Sea Cucumbers in Sunsak Bay, East Lombok E\&ES, 4411012005

[7] A. Faisal 2004 Rekontruksi Syariat Islam: Studi tentang Pandangan Ulama Terhadap Syariat Islam di Sulawesi Selatan Disertasi UIN Sunan Kalijaga Yogyakarta.

[8] A. S. Ma'arif 1985 Islam dan Masalah Kenegaraan: Studi tentang Percaturan dalam Konstituant Lembaga Penelitian Pendidikan dan Penerangan Ekonomi dan Sosial.

[9] AR, Amril Maryolo 2019 Syariat dan Perundang-Undangan: Proses Kebijakan dan Konten Perda Keagamaan di Bulukumba Mazahibuna, 11

[10] K. R. McGannon, B. Smith, K. Kendellen, \& C. A. Gonsalves 2019 Qualitative research in six sport and exercise psychology journals between 2010 and 2017: An updated and expanded review of trends and interpretations International Journal of Sport and Exercise Psychology, 1-21

[11] A. C. Singh, V. Beresovsky, \& C. Ye 2017 Estimation from purposive samples with the aid of probability supplements but without data on the study variable 2017 JSM Proceedings, ASA Section on the Survey Research Method Section.

[12] M. R. Fisher, T. Workman, A. Mulyana, B. Institute, M. Moeliono, E. L. Yuliani, ... \& U. E. F. B. Adam 2017 Striving for PAR excellence in land use planning: Multi-stakeholder collaboration on customary forest recognition in Bulukumba, South Sulawesi Land Use Policy. 
[13] A. C. Nur, H. Akib, R. Niswaty, A. Aslinda, \& H. Zaenal 2019 Development Partnership Strategy Tourism Destinations Integrated and Infrastructure in South Sulawesi Indonesia Available at SSRN 3497230

[14] A. Tahir, L. Sultan, D. Syamsuddin, \& M. Sabri 2019 Direct Election System In City of Makassar In Islamic Law Perspective Journal of Research and Multidisciplinary, 2 1 71-83

[15] G. Joffé 2019 Party dualities: Where does political Islam go now? Mediterranean Politics, 242 218-236

[16] I. Noor 2019 Globalization, Nation-State, and Local Identity A Study of an Affair between the Movement of Religious Formalization and the Discourse of Local Identity in Kalimantan Selatan Asia-Pacific Journal on Religion and Society, 22 96-111

[17] H. A. Syarifuddin Mantan Kepala Kantor Kementerian Agama Kabupaten Bulukumba Wawancara Pribadi (Bulukumba, 19 Mei 2020).

[18] A. P. Pabokori Mantan Bupati Bulukumba Periode Tahun 1995 Wawancara Pribadi (Makassar, 19 Mei 2020).

[19] Sahiruddin Mantan Ketua Umum BKPRMI Kabupaten Bulukumba Wawancara Pribadi (Bulukumba, 19 Mei 2020).

[20] M. Idris, E. Willya, I. S. Wekke, \& S. Mokodenseho 2020 Peace Resolution in Education and Application on Information and Communication Technologhy International Journal of Advanced Science and Technology, $2963349-3358$

[21] P. D. Dalmeri, Dilema antara Penerapan Syariat Islam dan Penegakan Hak Asasi Manusia di Indonesia Salam: Jurnal Studi Masyarakat Islam, 15 